\title{
Exceptional $\mathrm{H}_{2}$ Saturation Uptake in Microporous Metal-Organic Frameworks (Supporting Information)
}

\author{
Antek G. Wong-Foy, Adam J. Matzger,* and Omar. M. Yaghi* \\ Department of Chemistry, University of Michigan, 930 North University Avenue, Ann Arbor, Michigan
} 48109, USA

\section{Soption Measurements}

\section{1. $\mathrm{N}_{2}$ surface areas}

$\mathrm{N}_{2}$ adsorption/desorption isotherms were measured volumetrically at $77 \mathrm{~K}$ in the range $1.00 \times 10^{-3} \leq \mathrm{p} / \mathrm{p}^{\mathrm{o}} \leq 1.00$ with an Autosorb-1C outfitted with the micropore option by Quantachrome Instruments (Boynton Beach, Florida USA), running version 1.2 of the ASWin software package. Ultra-high purity $\mathrm{He}(99.999 \%$, for void volume determination) and $\mathrm{N}_{2}$ (99.999\%) were purchased from Cryogenic Gasses and used as received. All $\mathrm{N}_{2}$ isotherms were measured using samples (typically 8-14 $\mathrm{mg}$ ) that were activated ex situ: that is, other than the initial evacuation of the sample in the sample cell for sorption measurements to commence, no other treatment of the sample was performed. This was done to ensure that the nature of the material used in the surface area measurements was the same as that being used in the high pressure $\mathrm{H}_{2}$ sorption experiments. Typically, $1 \mathrm{~g}$ of the MOF material was activated ${ }^{1}$ and thereafter was handled and stored using standard Schlenk techniques. For all the $\mathrm{Zn}_{4} \mathrm{O}$ based MOFs, exposure to ambient atmosphere did not degrade the material substantially and thus these materials could be handled in air for short periods of time. However, for both MOF-74 and HKUST-1, considerable decreases in surface were observed after only a few minutes of exposure to air. These samples were thus loaded into sample cells in an inert atmosphere $\left(\mathrm{N}_{2}\right)$ glovebox.

Type I isotherms were observed for all MOFs as previously described. Strictly speaking, the mechanism of adsorption in microporous materials (pores $<2 \mathrm{~nm}$ ) is porefilling as opposed to mono-multi layer adsorption. Therefore, application of the Langmuir or Brunauer, Emmett, Teller (BET) methods only gives rise to apparent surface areas and are reported in order to facilitate comparisons with other materials. The linear region of the $\mathrm{N}_{2}$ isotherm used for the BET plot was $0.02 \leq \mathrm{p} / \mathrm{p}^{\mathrm{o}} \leq 0.1$, and for the Langmuir plot the range was $0.02 \leq \mathrm{p} / \mathrm{p}^{\circ} \leq 0.35$.

Previously reported surface area measurements were performed in a gravimetric apparatus wherein the sample to be analyzed ( 100-150 mg) was contained in a quartz bucket (h x o.d. x i.d. $=30 \mathrm{~mm} \times 19 \mathrm{~mm} \times 17 \mathrm{~mm}$ ) suspended from the balance arm of a Cahn C-100 microgravimetric balance. The entire assembly is enclosed in glass, and in particular the suspended bucket is enclosed by a glass tube with an i.d. of $45 \mathrm{~mm}$. Cooling of the sample and the surrounding atmosphere was achieved by submerging the tube in a liquid nitrogen bath. Compared to the volumetric apparatus, where the sample is in direct contact with the walls of the sample cell which in turn is submerged in liquid nitrogen, the thermal contact between the sample and the coolant in the gravimetric method is less efficient leading to higher sample temperatures and thus underestimating $\mathrm{N}_{2}$ uptake. $^{2}$ 
Table S1: Apparent surface areas and pore volumes for MOFs measured volumetrically at $77 \mathrm{~K}$.

\begin{tabular}{|l|c|c|c|}
\hline Material & $\begin{array}{c}\text { Crystal density }^{a} \\
\left(\mathrm{~g} / \mathrm{cm}^{3}\right)\end{array}$ & $\begin{array}{c}\mathrm{S}_{\mathrm{L}} \\
\left(\mathrm{m}^{2} / \mathrm{g}\right)\end{array}$ & $\begin{array}{c}\mathrm{S}_{\mathrm{BET}} \\
\left(\mathrm{m}^{2} / \mathrm{g}\right)\end{array}$ \\
\hline MOF-74 & 1.22 & 1072 & 950 \\
HKUST-1 & 0.879 & 2257 & 1944 \\
IRMOF-11 & 0.760 & 2337 & 1984 \\
IRMOF-6 & 0.653 & 3305 & 2804 \\
IRMOF-1 & 0.590 & 4171 & 3534 \\
IRMOF-20 & 0.511 & 4593 & 4024 \\
MOF-177 & 0.427 & 5640 & 4746 \\
\hline
\end{tabular}

${ }^{a}$ Calculated density with all guests removed.

\section{High pressure $\mathrm{H}_{2}$ sorption}

Equilibrium $\mathrm{H}_{2}$ adsorption/desorption isotherms were measured using the static volumetric method ${ }^{3}$ in an HPA-100 (High Pressure Analyzer) from the VTI Corporation, Hialeah, Fl, USA (www.vticorp.com) shown in Figure S1. High pressure pneumatically operated valves allow delivery of gasses in and out of the system and can be controlled manually at the instrument or via an attached computer. The system is equipped with two electronic Bourdon gauge-type transducers (Mensor) that cover the range $0-1500$ psi (accuracy $0.010 \%$ full scale): one is used to measure the pressure in the dosing manifold, while the other monitors the pressure in the sample cell. The working temperature of the manifold is kept at $45^{\circ} \mathrm{C}$ by heating the manifold compartment. Vacuum is provided by a TSH 071 E turbomolecular pumping station (Pfeiffer) capable of reaching pressures of < $1 \times 10^{-6}$ mbar. The sample cell is a 2-piece assembly that consists of a sample chamber ( $4 \mathrm{~mL}$ ) and a high pressure bellows valve. The two are connected via 1/4" VCR fittings and the materials of construction are all 316 stainless steel. Connection to the system is achieved by a $1 / 4$ " VCO fitting. Two ports are available: one for outgassing the sample (located on the vacuum side in Fig. 1S) and an analysis port, outfitted to hold either a thermostated recirculating bath or a small cryogenic dewar. Ultra-high purity $\mathrm{He}$ (99.999\%) and $\mathrm{H}_{2}$ (99.999\%) were purchased from Cryogenic Gasses and used as received. In a typical experiment 300-500 $\mathrm{mg}$ of an ex situ activated sample was charged into the cell and evacuated at room temperature to $10^{-6}$ mbar prior to sorption experiments. As above, the $\mathrm{Zn}_{4} \mathrm{O}$ based MOFs, could be handled in air for short periods of time, whereas MOF-74 and HKUST-1 were handled in the glovebox.

WARNING: Hydrogen gas is highly flammable even at low concentrations and thus care must be taken when working with $\mathrm{H}_{2}$ at high pressures. Efficient ventilation of the area where the experiments are carried out is necessary and a hydrogen detector should be employed. 


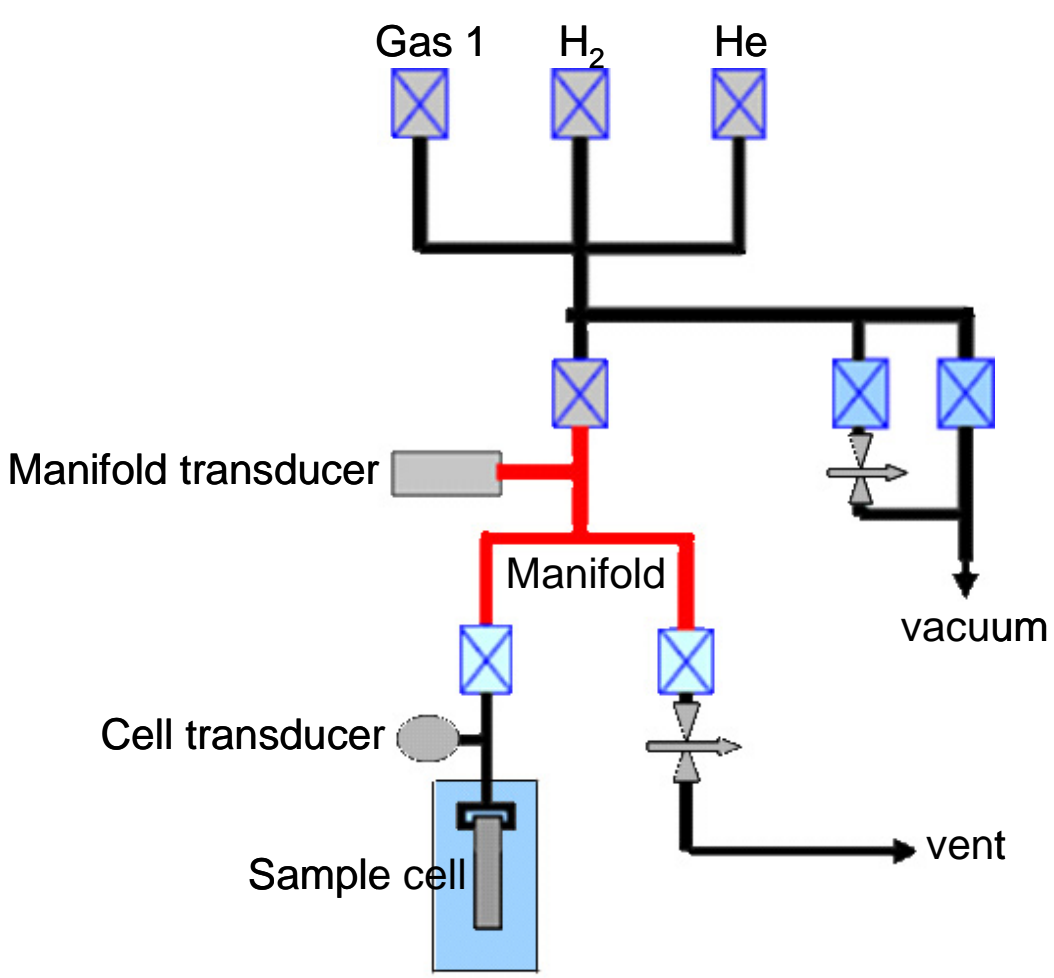

Thermostated bath

Figure S1. Flow diagram of HPA-100 apparatus. Three gas ports are available: one is dedicated for He and the other two are for adsorbate gasses of interest.

Prior to $\mathrm{H}_{2}$ sorption the void volume $\left(V_{\text {void }}\right)$ of the cell is determined by using $\mathrm{He}$ gas, and assuming that the amount of He adsorbed is negligible. This can be determined from the following relations

$$
\begin{aligned}
V_{\text {void }} & =n_{H e}\left(Z_{H e} R T / P\right)_{\text {cell }} \\
n_{H e} & =\left(P V /\left(Z_{H e} R T\right)\right)_{\text {man }}
\end{aligned}
$$

Here $n_{H e}$ is the number of moles of helium in the manifold (man) that is admitted to the cell, $Z_{H e}$ is the compression factor of $\mathrm{He}, R$ is the gas constant, and $T$ is the temperature, and the subscripts "cell" and "man" refer to conditions in the cell and manifold respectively. The compressibility factor $Z_{\mathrm{He}}=\mathrm{Z}_{\mathrm{He}}(\mathrm{P}, \mathrm{T})$ is thus a function of temperature and pressure and can be determined from its thermal equation of state (EOS). This is accomplished in the HPA software by utilizing the NIST RefProp program (Version 7.0) and the NIST Standard Reference Data Base 23 (See Fig S2) 


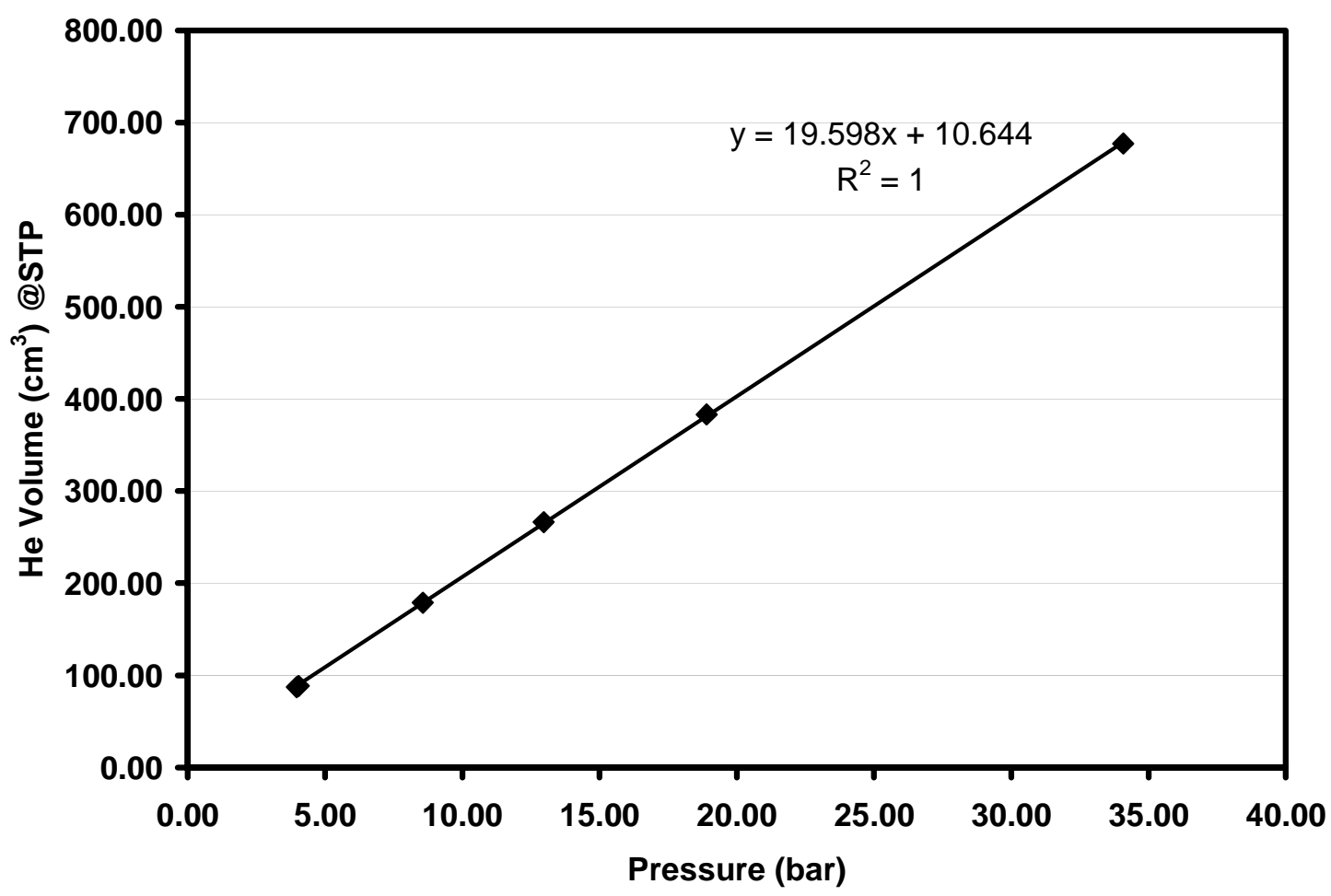

Figure S2. Typical void volume determination at $77 \mathrm{~K}$ with $\mathrm{He}$ gas. The slope $\left(n_{\mathrm{He}}\right)$ is the number of moles of He in the cell.

$\mathrm{H}_{2}$ isotherms were measured at $77 \mathrm{~K}$ from 0 to 90 bar on the adsorption side and from $80-4$ bar on the desorption side. Using $\mathrm{V}_{\text {void }}$ and the calculated compressibility factors of $\mathrm{H}_{2}$ obtained from the NIST RefProp program, the amount of adsorbed $\mathrm{H}_{2}\left(n_{\text {ads }}\right)$ can now be calculated from:

$$
\begin{gathered}
n_{\text {ads }}=n_{\text {man }}-n_{\text {void }} \\
n_{\text {man }}=\left(\left(P_{1} V / Z_{H_{2}}^{1} R T_{1}\right)-\left(P_{2} V / Z_{H_{2}}^{2} R T_{2}\right)\right)_{\text {man }} \\
n_{\text {void }}=\left(P V / Z_{\mathrm{H}_{2}} R T\right)_{\text {cell }}
\end{gathered}
$$

$P_{1}, T_{1}, Z_{H 2}^{1}$ and $P_{2}, T_{2}, Z_{H 2}^{2}$ are the pressure, temperature and compression factor of the $\mathrm{H}_{2}$ at equilibrium in the manifold before and after dosing the sample cell. $P, T$, and $Z_{H 2}$, are the corresponding pressure, temperature, and compression factor of the $\mathrm{H}_{2}$ at equilibrium in the sample cell.

Adsorption isotherms will always exhibit a maximum if carried out to a high enough pressure. The reason being that the isotherms collected are excess adsorption measurements, which means that the amount of gas adsorbed $\Delta \mathrm{g}$ is the amount of gas in excess of the bulk gas that would normally occupy the dead volume or free space of the adsorbent at a given temperature and pressure. As the pressure increases a maximum uptake will eventually be reached and this adsorbed layer will have a maximum density $\left(\rho_{\mathrm{a}}\right)$ and a volume of $V_{a}$. By further increasing the pressure, the density of the gas phase 
$\left(\rho_{\mathrm{g}}\right)$ will approach the density of the adsorbed phase. At $\rho_{\mathrm{g}}=\rho_{\mathrm{a}}$, the amount adsorbed will be calculated to be zero by the definition of adsorption.

$$
\Delta g=V_{a}\left(\rho_{a}-\rho_{g}\right)
$$

Further increase in the pressure of the gas results in $\rho_{\mathrm{g}}>\rho_{\mathrm{a}}$. The result is an apparent decrease in the isotherm even though the pressure continues to rise. ${ }^{4}$ 
Table S2. $\mathrm{H}_{2}$ sorption data for MOFs at $77 \mathrm{~K}$.

\begin{tabular}{|c|c|c|c|}
\hline \multicolumn{4}{|c|}{ IRMOF-1 } \\
\hline $\begin{array}{c}\text { Pressure } \\
\text { (bar) }\end{array}$ & $\begin{array}{c}\text { Vol (STP) } \\
\left(\mathrm{cm}^{3} / \mathrm{g}\right)\end{array}$ & $\begin{array}{c}\text { Gravimetric } \\
\text { Uptake } \\
(\mathrm{mg} / \mathrm{g})\end{array}$ & $\begin{array}{c}\text { Volumetric } \\
\text { Uptake } \\
(\mathrm{g} / \mathrm{L})\end{array}$ \\
\hline 0.5 & 66.5 & 6.0 & 3.5 \\
1.1 & 128.6 & 11.6 & 6.8 \\
1.7 & 173.8 & 15.6 & 9.2 \\
2.2 & 206.6 & 18.6 & 11.0 \\
2.9 & 243.0 & 21.9 & 12.9 \\
4.1 & 294.9 & 26.5 & 15.7 \\
5.6 & 345.7 & 31.1 & 18.3 \\
7.7 & 396.3 & 35.7 & 21.0 \\
10.4 & 443.8 & 39.9 & 23.6 \\
13.1 & 478.7 & 43.1 & 25.4 \\
15.9 & 504.0 & 45.4 & 26.7 \\
19.8 & 527.7 & 47.5 & 28.0 \\
25.1 & 549.5 & 49.5 & 29.2 \\
33.8 & 569.4 & 51.2 & 30.2 \\
45.4 & 579.5 & 52.1 & 30.8 \\
57.5 & 577.1 & 51.9 & 30.6 \\
68.3 & 569.0 & 51.2 & 30.2 \\
78.1 & 545.9 & 49.1 & 29.0 \\
87.9 & 529.1 & 47.6 & 28.1 \\
82.5 & 550.2 & 49.5 & 29.2 \\
66.8 & 566.2 & 51.0 & 30.0 \\
48.5 & 583.5 & 52.5 & 31.0 \\
32.4 & 571.3 & 51.4 & 30.3 \\
20.5 & 539.0 & 48.5 & 28.6 \\
12.5 & 478.8 & 43.1 & 25.4 \\
10.2 & 449.0 & 40.4 & 23.8 \\
\hline & & & \\
\hline
\end{tabular}


Table S2 continued.

\begin{tabular}{|c|c|c|c|}
\hline \multicolumn{5}{|c|}{ IRMOF-6 } \\
\hline $\begin{array}{c}\text { Pressure } \\
\text { (bar) }\end{array}$ & $\begin{array}{c}\text { Vol (STP) } \\
\left(\mathrm{cm}^{3} / \mathrm{g}\right)\end{array}$ & $\begin{array}{c}\text { Gravimetric } \\
\text { Uptake } \\
(\mathrm{mg} / \mathrm{g})\end{array}$ & $\begin{array}{c}\text { Volumetric } \\
\text { Uptake } \\
(\mathrm{g} / \mathrm{L})\end{array}$ \\
\hline 0.4 & 67.5 & 6.1 & 4.0 \\
1.0 & 132.5 & 11.9 & 7.8 \\
1.6 & 180.7 & 16.3 & 10.6 \\
2.1 & 216.1 & 19.4 & 12.7 \\
3.1 & 266.3 & 24.0 & 15.6 \\
4.3 & 311.6 & 28.0 & 18.3 \\
5.6 & 351.6 & 31.6 & 20.7 \\
7.7 & 395.8 & 35.6 & 23.2 \\
10.4 & 434.2 & 39.1 & 25.5 \\
13.1 & 461.3 & 41.5 & 27.1 \\
15.9 & 482.4 & 43.4 & 28.3 \\
20.0 & 500.0 & 45.0 & 29.4 \\
25.0 & 519.2 & 46.7 & 30.5 \\
33.7 & 530.0 & 47.7 & 31.1 \\
45.3 & 538.6 & 48.5 & 31.6 \\
57.2 & 539.4 & 48.5 & 31.7 \\
68.3 & 531.3 & 47.8 & 31.2 \\
78.3 & 507.0 & 45.6 & 29.8 \\
88.1 & 493.0 & 44.4 & 29.0 \\
82.8 & 510.4 & 45.9 & 30.0 \\
66.7 & 534.6 & 48.1 & 31.4 \\
48.7 & 537.0 & 48.3 & 31.5 \\
32.2 & 535.1 & 48.2 & 31.4 \\
20.0 & 510.4 & 45.9 & 30.0 \\
12.1 & 458.6 & 41.3 & 26.9 \\
7.4 & 394.1 & 35.5 & 23.2 \\
\hline & & & \\
\hline
\end{tabular}


Table $\mathbf{S} 2$ continued.

\begin{tabular}{|c|c|c|c|}
\hline \multicolumn{4}{|c|}{ IRMOF-11 } \\
\hline $\begin{array}{c}\text { Pressure } \\
\text { (bar) }\end{array}$ & $\begin{array}{c}\text { Vol (STP) } \\
\left(\mathrm{cm}^{3} / \mathrm{g}\right)\end{array}$ & $\begin{array}{c}\text { Gravimetric } \\
\text { Uptake } \\
(\mathrm{mg} / \mathrm{g})\end{array}$ & $\begin{array}{c}\text { Volumetric } \\
\text { Uptake } \\
(\mathrm{g} / \mathrm{L})\end{array}$ \\
\hline 0.2 & 64.5 & 5.8 & 4.4 \\
0.5 & 115.5 & 10.4 & 7.9 \\
1.0 & 168.2 & 15.1 & 11.5 \\
1.7 & 211.1 & 19.0 & 14.4 \\
2.7 & 251.9 & 22.7 & 17.2 \\
4.1 & 284.1 & 25.6 & 19.4 \\
5.8 & 312.2 & 28.1 & 21.3 \\
8.4 & 337.9 & 30.4 & 23.1 \\
11.1 & 354.9 & 31.9 & 24.3 \\
13.3 & 365.0 & 32.9 & 25.0 \\
15.6 & 372.3 & 33.5 & 25.5 \\
19.3 & 380.8 & 34.3 & 26.0 \\
24.8 & 385.9 & 34.7 & 26.4 \\
33.7 & 390.6 & 35.2 & 26.7 \\
45.5 & 388.1 & 34.9 & 26.5 \\
57.3 & 384.0 & 34.6 & 26.3 \\
67.8 & 375.7 & 33.8 & 25.7 \\
77.4 & 363.1 & 32.7 & 24.8 \\
87.8 & 344.0 & 31.0 & 23.5 \\
82.7 & 353.9 & 31.8 & 24.2 \\
66.5 & 374.6 & 33.7 & 25.6 \\
48.0 & 394.2 & 35.5 & 27.0 \\
31.6 & 397.4 & 35.8 & 27.2 \\
19.8 & 382.6 & 34.4 & 26.2 \\
11.6 & 358.3 & 32.2 & 24.5 \\
6.5 & 320.9 & 28.9 & 21.9 \\
\hline & & & \\
\hline
\end{tabular}


Table $\mathbf{S} 2$ continued.

\begin{tabular}{|c|c|c|c|}
\hline \multicolumn{4}{|c|}{ IRMOF-20 } \\
\hline $\begin{array}{c}\text { Pressure } \\
\text { (bar) }\end{array}$ & $\begin{array}{c}\text { Vol (STP) } \\
\left(\mathrm{cm}^{3} / \mathrm{g}\right) \\
\end{array}$ & $\begin{array}{c}\text { Gravimetric } \\
\text { Uptake } \\
(\mathrm{mg} / \mathrm{g})\end{array}$ & $\begin{array}{c}\text { Volumetric } \\
\text { Uptake } \\
(\mathrm{g} / \mathrm{L})\end{array}$ \\
\hline 0.7 & 88.7 & 8.0 & 4.1 \\
\hline 1.3 & 144.3 & 13.0 & 6.6 \\
\hline 2.0 & 195.3 & 17.6 & 9.0 \\
\hline 2.6 & 229.4 & 20.6 & 10.5 \\
\hline 3.6 & 282.0 & 25.4 & 13.0 \\
\hline 5.0 & 337.4 & 30.4 & 15.5 \\
\hline 6.1 & 369.1 & 33.2 & 17.0 \\
\hline 7.6 & 411.3 & 37.0 & 18.9 \\
\hline 9.9 & 459.6 & 41.4 & 21.1 \\
\hline 12.6 & 504.8 & 45.4 & 23.2 \\
\hline 15.6 & 544.4 & 49.0 & 25.0 \\
\hline 19.9 & 586.1 & 52.7 & 27.0 \\
\hline 25.2 & 624.6 & 56.2 & 28.7 \\
\hline 33.8 & 670.5 & 60.3 & 30.8 \\
\hline 45.3 & 707.3 & 63.7 & 32.5 \\
\hline 57.4 & 730.4 & 65.7 & 33.6 \\
\hline 68.3 & 737.5 & 66.4 & 33.9 \\
\hline 77.6 & 741.5 & 66.7 & 34.1 \\
\hline 87.6 & 737.6 & 66.4 & 33.9 \\
\hline 83.4 & 725.2 & 65.3 & 33.3 \\
\hline 67.3 & 747.6 & 67.3 & 34.4 \\
\hline 48.9 & 727.0 & 65.4 & 33.4 \\
\hline 32.3 & 677.3 & 61.0 & 31.1 \\
\hline 20.4 & 603.0 & 54.3 & 27.7 \\
\hline 12.3 & 513.4 & 46.2 & 23.6 \\
\hline 7.2 & 409.3 & 36.8 & 18.8 \\
\hline
\end{tabular}


Table $\mathbf{S} 2$ continued.

\begin{tabular}{|c|c|c|c|}
\hline \multicolumn{4}{|c|}{ MOF-177 } \\
\hline $\begin{array}{c}\text { Pressure } \\
\text { (bar) }\end{array}$ & $\begin{array}{c}\text { Vol (STP) } \\
\left(\mathrm{cm}^{3} / \mathrm{g}\right)\end{array}$ & $\begin{array}{c}\text { Gravimetric } \\
\text { Uptake } \\
(\mathrm{mg} / \mathrm{g})\end{array}$ & $\begin{array}{c}\text { Volumetric } \\
\text { Uptake } \\
(\mathrm{g} / \mathrm{L})\end{array}$ \\
\hline 0.9 & 109.7 & 9.9 & 4.2 \\
1.4 & 156.5 & 14.1 & 6.0 \\
2.4 & 229.7 & 20.7 & 8.8 \\
2.9 & 265.4 & 23.9 & 10.2 \\
3.8 & 312.8 & 28.1 & 12.0 \\
4.9 & 368.7 & 33.2 & 14.2 \\
6.4 & 425.1 & 38.3 & 16.3 \\
8.2 & 482.3 & 43.4 & 18.5 \\
10.4 & 537.9 & 48.4 & 20.7 \\
12.7 & 584.3 & 52.6 & 22.4 \\
15.5 & 626.8 & 56.4 & 24.1 \\
19.6 & 675.4 & 60.8 & 25.9 \\
25.0 & 721.1 & 64.9 & 27.7 \\
33.8 & 772.3 & 69.5 & 29.7 \\
45.5 & 814.0 & 73.3 & 31.3 \\
57.6 & 832.9 & 75.0 & 32.0 \\
68.5 & 835.3 & 75.2 & 32.1 \\
77.8 & 828.9 & 74.6 & 31.8 \\
87.7 & 810.7 & 73.0 & 31.1 \\
81.4 & 819.6 & 73.8 & 31.5 \\
65.8 & 832.2 & 74.9 & 32.0 \\
48.3 & 820.7 & 73.9 & 31.5 \\
32.4 & 775.5 & 69.8 & 29.8 \\
20.7 & 699.6 & 63.0 & 26.9 \\
13.1 & 602.8 & 54.2 & 23.2 \\
8.5 & 505.1 & 45.5 & 19.4 \\
5.4 & 401.2 & 36.1 & 15.4 \\
\hline & & & \\
\hline
\end{tabular}


Table S2 continued.

\begin{tabular}{|c|c|c|c|}
\hline \multicolumn{4}{|c|}{ MOF-74 } \\
\hline $\begin{array}{c}\text { Pressure } \\
\text { (bar) }\end{array}$ & $\begin{array}{c}\text { Vol (STP) } \\
\left(\mathrm{cm}^{3} / \mathrm{g}\right)\end{array}$ & $\begin{array}{c}\text { Gravimetric } \\
\text { Uptake } \\
(\mathrm{mg} / \mathrm{g})\end{array}$ & $\begin{array}{c}\text { Volumetric } \\
\text { Uptake } \\
(\mathrm{g} / \mathrm{L})\end{array}$ \\
\hline 0.0 & 50.9 & 4.6 & 5.6 \\
0.3 & 113.1 & 10.2 & 12.4 \\
1.0 & 151.4 & 13.6 & 16.6 \\
1.9 & 175.1 & 15.8 & 19.2 \\
2.9 & 192.2 & 17.3 & 21.1 \\
4.7 & 208.7 & 18.8 & 22.9 \\
6.6 & 221.0 & 19.9 & 24.2 \\
8.6 & 229.2 & 20.6 & 25.1 \\
10.6 & 235.6 & 21.2 & 25.9 \\
14.3 & 242.8 & 21.9 & 26.6 \\
19.8 & 248.8 & 22.4 & 27.3 \\
26.1 & 251.1 & 22.6 & 27.6 \\
36.8 & 248.7 & 22.4 & 27.3 \\
49.9 & 250.7 & 22.6 & 27.5 \\
60.1 & 246.0 & 22.1 & 27.0 \\
70.7 & 237.9 & 21.4 & 26.1 \\
88.2 & 219.1 & 19.7 & 24.0 \\
82.9 & 228.2 & 20.5 & 25.0 \\
70.1 & 244.0 & 22.0 & 26.8 \\
57.6 & 256.0 & 23.0 & 28.1 \\
46.5 & 261.7 & 23.6 & 28.7 \\
36.6 & 264.5 & 23.8 & 29.0 \\
27.6 & 263.0 & 23.7 & 28.9 \\
18.8 & 261.0 & 23.5 & 28.6 \\
12.0 & 250.9 & 22.6 & 27.5 \\
7.4 & 228.2 & 20.5 & 25.0 \\
& & & \\
\hline & & & \\
\hline
\end{tabular}


Table S2 continued.

\begin{tabular}{|c|c|c|c|}
\hline \multicolumn{4}{|c|}{ HKUST-1 } \\
\hline $\begin{array}{c}\text { Pressure } \\
\text { (bar) }\end{array}$ & $\begin{array}{c}\text { Vol (STP) } \\
\left(\mathrm{cm}^{3} / \mathrm{g}\right)\end{array}$ & $\begin{array}{c}\text { Gravimetric } \\
\text { Uptake } \\
(\mathrm{mg} / \mathrm{g})\end{array}$ & $\begin{array}{c}\text { Volumetric } \\
\text { Uptake } \\
(\mathrm{g} / \mathrm{L})\end{array}$ \\
\hline 0.3 & 109.4 & 9.8 & 8.7 \\
0.7 & 165.4 & 14.9 & 13.1 \\
1.5 & 212.3 & 19.1 & 16.8 \\
2.7 & 244.7 & 22.0 & 19.4 \\
4.5 & 269.1 & 24.2 & 21.3 \\
8.0 & 293.3 & 26.4 & 23.2 \\
12.0 & 307.9 & 27.7 & 24.4 \\
16.2 & 316.7 & 28.5 & 25.1 \\
20.7 & 323.3 & 29.1 & 25.6 \\
25.6 & 331.8 & 29.9 & 26.3 \\
30.8 & 337.1 & 30.3 & 26.7 \\
36.0 & 340.7 & 30.7 & 27.0 \\
43.7 & 345.7 & 31.1 & 27.4 \\
54.2 & 350.7 & 31.6 & 27.7 \\
66.0 & 352.5 & 31.7 & 27.9 \\
76.8 & 362.5 & 32.6 & 28.7 \\
87.3 & 353.4 & 31.8 & 28.0 \\
81.6 & 355.3 & 32.0 & 28.1 \\
66.1 & 358.1 & 32.2 & 28.3 \\
48.2 & 353.9 & 31.8 & 28.0 \\
31.7 & 345.9 & 31.1 & 27.4 \\
19.5 & 331.1 & 29.8 & 26.2 \\
11.6 & 313.0 & 28.2 & 24.8 \\
7.1 & 294.5 & 26.5 & 23.3 \\
3.9 & 269.8 & 24.3 & 21.3 \\
\hline & & & \\
\hline
\end{tabular}




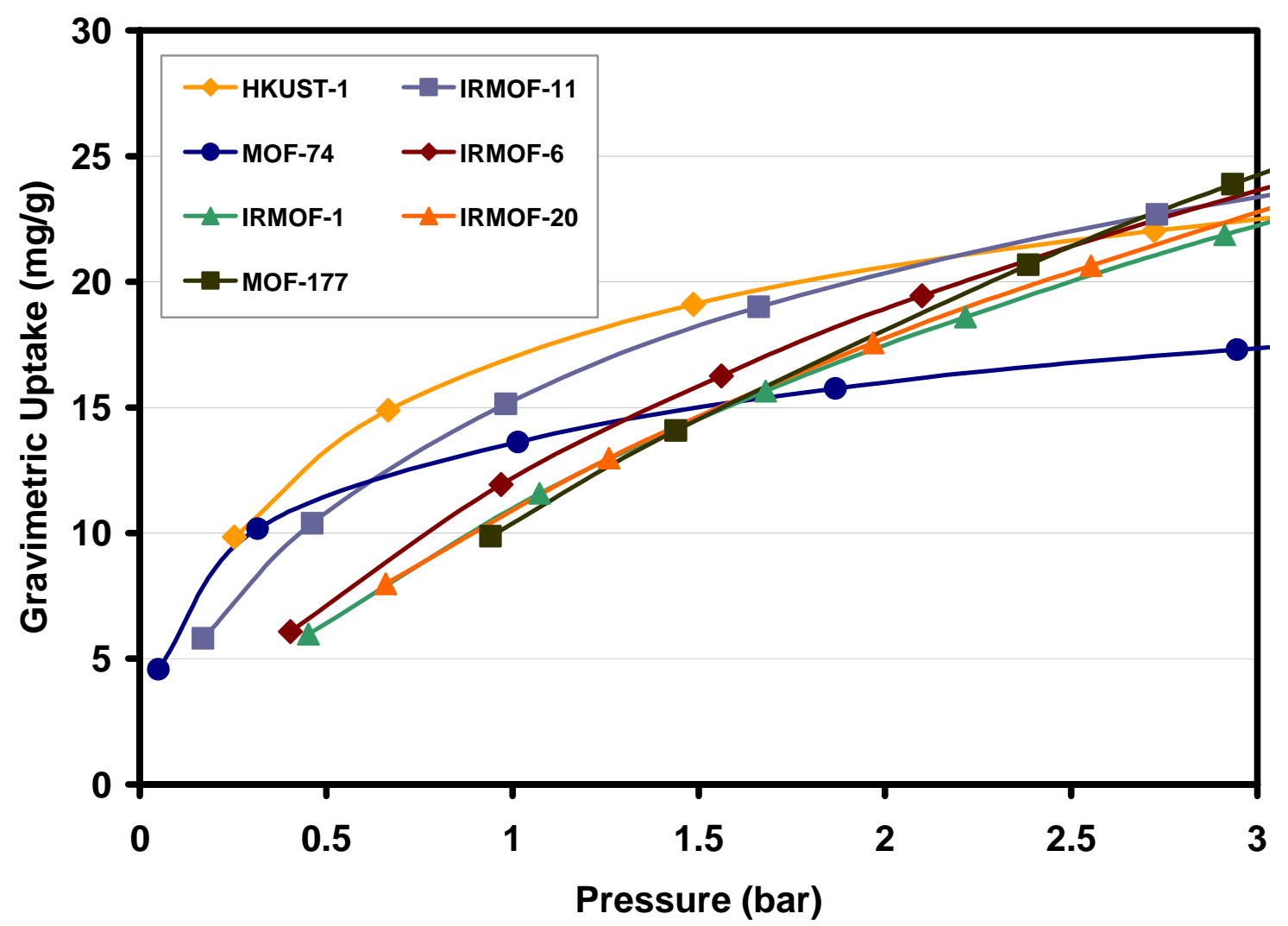

Figure S3. Magnified view of the low pressure region of the $\mathrm{H}_{2}$ adsorption isotherm showing high initial uptake of gas for HKUST-1, MOF-74, and IRMOF-11 in the region $<1$ bar.

${ }^{1}$ See refs 5 and 6 in the paper.

${ }^{2}$ Rouquerol, F.; Rouquerol, J.; Sing, K. Adsorption by Powders and Porous Solids Principle, Methodology, and Applications; Academic Press: San Diego, CA, 1999, p 61.

3 Keller, J.; staudt, R. Gas Adsorption Equilibria: Experimental Methods and Adsorption Isotherms; Springer Science+Business Media: New York, 2005, Chapter 2.

${ }^{4}$ Menon, P. G. Chem. Rev. 1968, 62, 277-294. 